\title{
IgA Nephropathy, Familal
}

National Cancer Institute

\section{Source}

National Cancer Institute. IgA Nephropathy, Familal. NCI Thesaurus. Code C123140.

IgA nephropathy secondary to a genetic mutation that is transmitted from parents to offspring. 